\title{
Epigenetic modifications in oral squamous cell carcinoma
}

\author{
Silas Antonio Juvencio de Freitas Filho, ${ }^{1}$ Wellington Francisco Rodrigues, ${ }^{2}$ Luiz Renato Paranhos, ${ }^{3}$ Sigmar de Mello Rode ${ }^{4}$ \\ ${ }^{1}$ Post-Graduate Program in Applied Dental Sciences, Bauru School of Dentistry, University of São Paulo (USP), Bauru, SP, Brazil \\ ${ }^{2}$ Post-Graduate Program in Health Sciences, Federal University of Triângulo Mineiro (UFTM), Uberaba, MG, Brazil \\ ${ }^{3}$ School of Dentistry, Federal University of Uberlândia (UFU), Uberlândia, MG, Brazil \\ ${ }^{4}$ School of Dentistry, Science and Technology Institute of São José dos Campos (UNESP), São José dos Campos, SP, Brazil \\ - Conflicts of interest: none declared.
}

\section{Introduction}

$\mathrm{O}$ ral cancer is considered a public health problem, and squamous cell carcinoma is the most frequent malignant neoplasm of the oral cavity. ${ }^{1}$ Despite scientific advances in recent years regarding the understanding of the disease and its prognosis biomarkers, much research is still required to better understand the molecular biology involving potential correlations to clinical pathological factors. ${ }^{2}$ Oral lesions with potential for malignant transformation may precede the development of squamous cell carcinoma, as is the case of leukoplakia, erythroplasia and erythroleukoplakia. ${ }^{3}$

The genetic changes in potentially malignant lesions and in squamous cell carcinoma of the oral mucosa are widely documented and explored; however, the studies involving epigenetic mechanisms are recent and scarce. ${ }^{4}$ Epigenetics refers to functional changes in genes after cell division without any modification in the sequence of bases of a DNA molecule. ${ }^{5}$ These changes are present during embryonic development, cellular growth and differentiation, aging, and in cancer, possibly constructing a code of histones that modulates the events subsequent to gene expression and, thus affects the organization of the chromatin. ${ }^{5,6}$ Dawson and Kouzarides ${ }^{7}$ highlighted that an abnormal expression of chromatin regulators can influence in the development of different types of cancer. The main types of epigenetic modifications are: DNA methylation, genomic imprinting and global histone modifications.

DNA methylation is possibly one of the early events in the development of malignant neoplasms. ${ }^{7,8}$ Global histone modifications are known to be altered in tumor cells, and modification patterns can show correlation with clinical pathological factors, including oral squamous cell carcinoma. ${ }^{9,10}$ In addition, a variety of global histone modifications have been studied in different types of cancer, many of which are used as prognosis predictors, especially the events of methylation and acetylation. ${ }^{11}$

Studies assessing the enzymes responsible for promotion of histone modifications have been conducted in several types of cancer, such as SUV39H1, a histone methyltransferase wherein imunoexpression displayed correlation with the tumor stage of oral squamous cell carcinoma. ${ }^{12}$ The potential roles SUV39H1 may assume have also been investigated regarding carcinogenesis of other cancers, such as that of the gastrointestinal tract. ${ }^{13}$ Research about squamous cell carcinoma of the lower lip also show participation of enzymes related to the process of acetylation in the carcinogenesis process. ${ }^{14}$ In addition, the exploration of epigenetic modifications can contribute to understanding the progression of actinic cheilitis, besides other intraoral potentially malignant disorders.

Several study tools are used for assessment of the expression of epigenetic modifications, among them the immunohistochemical method, a technique of quick and easy implementation available in many diagnostic and research laboratories, which allows for identification of antigens in tissue samples and, occasionally, determination of the correlation with clinical pathological factors. It is clear that further research on the participation of epigenetic changes in oral squamous cell carcinoma, especially global histone modifications and enzymes related to these events, must be performed so that the results achieved can help in early disease diagnosis and even identify the most aggressive cases.

\section{References}

1. Vasconcelos AC, Aburad C, Lima IFP, Santos SMM, Freitas SAJ Filho, Franco A, et al. A scientific survey on 1550 cases of oral lesions diagnosed in a Brazilian referral center. An Acad Bras Ciênc. 2017;89(3):1691-7.

2. Blatt S, Krüger M, Ziebart T, Sagheb K, Schiegnitz E, Goetze E, Al-Nawas B, et al. Biomarkers in diagnosis and therapy of oral squamous cell carcinoma: A review of the literature. J Craniomaxillofac Surg. 2017;45(5):722-30.

3. Mello FW, Melo G, Meurer MI, Rivero ERC. Intraoral Potentially Malignant Disorders in a Brazilian Oral Pathology Service: Epidemiological, Clinical, and Histopathological Findings. J Oncol. 2018; 2018, Article ID 2325808, 7 pages.

4. González-Ramírez I, García-Cuellar C, Sánchez-Pérez Y, Granados-García M. DNA methylation in oral squamous cell carcinoma: molecular mechanisms and clinical implications. Oral Dis. 2011;17(8):771-8.

5. Taby R, Issa JP. Cancer epigenetics. CA Cancer J Clin. 2010;60(6):376-92.

6. Roach HI, Bronner F, Oreffo ROC. Epigenetic Aspects of Chronic Diseases. Springer-Verlag London Limited, 2011.

7. Dawson MA, Kouzarides T. Cancer epigenetics: from mechanism to therapy. Cell. 2012;150(1):12-27.

8. Minardi D, Lucarini G, Filosa A, Milanese G, Zizzi A, Di Primio R, et al. Prognos- 
tic role of global DNA-methylation and histone acetylation in pTla clear cell renal carcinoma in partial nephrectomy specimens. J Cell Mol Med. 2009;13(8B):2115-21. 9. Webber LP, Wagner VP, Curra M, Vargas PA, Meurer L, Carrard VC, et al. Hypoacetylation of acetyl-histone $\mathrm{H} 3(\mathrm{H} 3 \mathrm{~K} 9 \mathrm{ac})$ as marker of poor prognosis in oral cancer. Histopathology. 2017;71(2):278-86.

10. Chen YW, Kao SY, Wang HJ, Yang MH. Histone modification patterns correlate with patient outcome in oral squamous cell carcinoma. Cancer. 2013;119(24):4259-67.

11. Chervona Y, Costa M. Histone modifications and cancer: biomarkers of prognosis? Am J Cancer Res. 2012;2(5):589-97.
12. Chen JH, Yet KT, Yang YM, Chang JG, Lee HE, Hung SY. High expressions of histone methylation- and phosphorylation-related proteins are associated with prognosis of oral squamous cell carcinoma in male population of Taiwan. Med Oncol. 2013;30(5):1-9.

13. Cai L, Ma X, Huang Y, Zou Y, Chen X. Aberrant histone methylation and the effect of Suv39H1 siRNA on gastric carcinoma. Oncol Rep. 2014;31(6):2593-600. 14. Chrun ES, Modolo F, Vieira D, Borges-Júnior A, Castro RG, Daniel FI. Immunoexpression of HDAC1, HDAC2, and HAT1 in actinic cheilitis and lip squamous cell carcinoma. Oral Dis. 2017;23(4):505-10.

\section{Mini Curriculum and Author's Contribution}

1. Silas Antonio Juvencio de Freitas Filho - DDS and PhD. Contribution: bibliographical research, manuscript preparation, critical review and final approval.

2. Wellington Francisco Rodrigues - DDS and PhD. Contribution: bibliographical research, manuscript preparation, critical review and final approval.

3. Luiz Renato Paranhos - DDS and PhD. Contribution: bibliographical research, manuscript preparation, critical review and final approval.

4. Sigmar de Mello Rode - DDS and PhD. Contribution: bibliographical research, manuscript preparation, critical review and final approval.

Submitted: 03/14/2018 / Accepted for publication: 04/20/2018

Corresponding Author

Sigmar de Mello Rode

E-mail: sigmarrode@uol.com.br 